Aloman 2018, 36(1), 51-61

Revista de Psicologia, Ciències de l'Educació i de l'Esport

ISSN: 1138-3194

Copyright (c) 2018

www.revistaaloma.net

\title{
Treatment of metabolic syndrome and quality of life in patients with schizophrenia: a systematic review
}

\author{
Maica Ruiz-Pérez ${ }^{1,3}$, Salvador Llistar-Verdú ${ }^{1,4}$, Laia Farràs-Permanyer ${ }^{1,2}$ \\ \& Tary Gómez-Hinojosa ${ }^{3}$ \\ ${ }^{1}$ Triginta Salut Mental - Fundació Vallparadis - MútuaTerrassa - Terrassa - España \\ 2 Departamento de Metodología de las Ciencias del Comportamiento - Facultad de Psicologia - Universitat \\ de Barcelona - Barcelona - España \\ ${ }^{3}$ Facultat Psicologia, Ciències de l'Educació i de l'Esport i Facultat de Ciències de la Salut Blanquerna - \\ Universitat Ramon Llull - Barcelona - España \\ ${ }^{4}$ Facultat Psicologia - Universidad Abad Oliba - Barcelona - España
}

Received: 19-03-2018

Accepted: 09-04-2018

Treatment of metabolic syndrome and quality of life in patients with schizophrenia: a systematic review

Summary: Schizophrenia affects around 0.3-0.7\% people at some point in their lives - or 24 million people worldwide. This review covers topics of broad general interest that have seen significant development or progress in recent years. This paper aims to review the scientific literature of the past 10 years on metabolic syndrome regarding the quality of life of people with schizophrenia and the interventions carried out. A bibliographical search was conducted on Web of Science and PsycINFO, using the keywords of this study. More than 90 publications were found, 70 of which met the requirements. The main topic was schizophrenia, metabolic syndrome and quality of life. Those that focused on the effects of drugs were excluded. Although the association between mental illness and physical health problems has been convincingly demonstrated, numerous studies support the existence of dual physical health care neglect of people with schizophrenia. On the other hand, the modifiable risk factors are clearly defined to improve the physical health of these patients as well as the aspects which should be included in any approach to improve metabolic syndrome in particular, physical health in general, and thus modify the selfperceived quality of life. The data on psychoeducational treatments for this population were insufficient. However, some studies show that the implementation of behavioral interventions in clinical practice can help patients improve their overall health and prevent chronic disease. There are few studies on the application of ehealth devices to schizophrenic patients.

Keywords: metabolic syndrome; quality of life; intervention; schizophrenia; theoretical study

Correspondence

Maica Ruiz Pérez

Triginta Salut Mental. Sant Antoni, 30 - 08221 - Terrassa

Teléfono: +34937365099

mruiz@fundaciovallparadis.es 
Tratamiento del síndrome metabólico y calidad de vida en pacientes con esquizofrenia: una revisión sistemática

Resumen. La esquizofrenia afecta a alrededor del 0,3-0,7\% de las personas en algún momento de su vida, o 24 millones de personas en todo el mundo. Esta revisión cubre temas que han visto un desarrollo o progreso significativo en los últimos años con amplio interés general. El objetivo de este trabajo es revisar la literatura científica de los últimos 10 años que hace referencia al síndrome metabólico en relación con la calidad de vida de las personas con esquizofrenia y las intervenciones que se han realizado al respecto. Se incluyeron los artículos recogidos en Web of Science y PsycINFO usando las palabras clave de este trabajo. Se encontraron más de 90 publicaciones de las cuales se incluyeron en la revisión las 70 que cumplían con los requisitos establecidos. El tema principal era la esquizofrenia, síndrome metabólico y la calidad de vida. Se excluyeron aquellos que se centraban en los efectos de los fármacos. Se encontraron abundantes estudios que avalan la existencia de una doble negligencia en la atención a la salud física de las personas con esquizofrenia a pesar de que se encuentra sólidamente demostrada la asociación entre enfermedad mental y problemas de salud física. Por otro lado, quedan claramente establecidos los factores de riesgo modificables para mejorar la salud física de estos pacientes así como los aspectos que debería incluir cualquier abordaje para mejorar el síndrome metabólico en particular, la salud física en general y así modificar la calidad de vida autopercibida. Los hallazgos más deficitarios han sido los que tienen relación a tratamientos psicoeducativos globales y evaluados para esta población. Sin embargo, algunos estudios indican que la implementación de las intervenciones conductuales en la práctica clínica puede ayudar a los pacientes a mejorar su estado general de salud y prevenir enfermedades crónicas. Existen muy pocos estudios de la aplicación de dispositivos ehealth en pacientes con esquizofrenia.

Palabras clave: síndrome metabólico; calidad de vida; intervención; esquizofrenia; estudio teórico 


\section{Introduction}

Schizophrenia affects around $0.3-0.7 \%$ people at some point in their lives, or 24 million people worldwide. People with schizophrenia are at a substantially increased risk of death compared to the general population. Specifically, it is 2.5 times higher than in the general population (Crawford et al, 2014; de Hert, Schreurs, Vancampfort \& van Winkel, 2009; Saha, Chant \& McGrath, 2007; Varela, Fernández, López, Nieto, Pereiro \& Gándara, 2013). Health problems are frequent in patients with schizophrenia, and these problems contribute to a higher death rate and a decline in quality of life (von Hausswolff, Bjartveit, Lindström \& Jones, 2009). The main problem this population faces is the presence of cardiovascular risk related with the disease itself, lifestyle and antipsychotic treatment.

There is scientific evidence that unequal treatment in healthcare provision plays an important role (Deuschle et al., 2013; Fagiolini \& Goracci, 2009; Maj, 2009a; Meyer et al., 2005;Millar, 2010;Rönngren, Björk, Haage \& Kristiansen, 2014;Saha et al., 2007;Sáiz-Ruiz, SaizGonzalez, Alegría, Mena, Luque \& Bobes, 2010;Viñas, Fernández \& Martín, 2013). This is so-called "dual negligence"; a term that refers to a failure to monitor the physical health of people with schizophrenia, attributable to both the patient and the healthcare system overall. People with schizophrenia are thought to be less likely to seek and use medical care, they engage in risk-taking behaviour often fail to comply with their treatment regimes (Saha et al., 2007). It is now recognized worldwide that identifying and dealing with physical illness would benefit individual patients, improving their quality of life, extending their life expectancy, and leading to improvements in their economic and social welfare (Pompili et al., 2011).

One physical disease is particularly prevalent among this population. These patients face a four-fold greater risk of metabolic syndrome (MetS) than the general population. The most common parameters to identify MetS are those proposed by the Adult Treatment Panel III (ATP III) of the National Cholesterol Education Program (NCEP) (Table 1).

Therefore, this disease is of considerable interest to professionals who treat patients with schizophrenia for two important reasons: 1) the high prevalence in this population; and 2) its association with decreased life

Tabla 1. MetS diagnostic criteria according to NCEP ( $\geq 3$ criteria must be met to establish the diagnosis)

\begin{tabular}{ll}
\hline Risk factor & Values \\
\hline Abdominal obesity & $\geq 102 \mathrm{~cm}$ \\
\hline Men & $\geq 88 \mathrm{~cm}$ \\
\hline Women & $\geq 110 \mathrm{mg} / \mathrm{dl}$ \\
\hline Fasting glucose & $\geq 150 \mathrm{mg} / \mathrm{dl}$ \\
\hline Triglycerides & $<40 \mathrm{mg} / \mathrm{dl}$ \\
\hline Men cholesterol & $<50 \mathrm{mg} / \mathrm{dl}$ \\
\hline Women & $\geq 130 / 85 \mathrm{~mm} / \mathrm{Hg}$ \\
\hline Blood pressure
\end{tabular}

expectancy (Meyer et al., 2005). Countless studies have examined the reasons people suffering from schizophrenia may have greater probabilities of developing MetS (Millar, 2008; Riordan, Antonini \& Murphy, 2011; Shuel, White, Jones \& Gray, 2010; Varela et al, 2013 ). These causes are:

- Overweight-Obesity: Patients with severe mental illness are about two to three times more likely than than the general population to be overweight or obese, with an especially marked tendency toward abdominal obesity

- Sedentary lifestyle: a common trait of this population.

- Poor nutrition: Their diets tend to be high in saturated fats and sugars.

- Smoking: The smoking prevalence rate is above 60\% for schizophrenic patients (Morris, Waxmonsky, May \& Giese, 2009). This figure reaches 70\% in Spain, according to Bernardo et al. (2009), which is 2-3 times higher than the general population.

- Side effects of antipsychotic medication.

- Genetic predisposition.

Thus, in light of the above we can see that MetS can largely be associated with a sedentary lifestyle.

Interest in the subject has increased enormously since the first article on MetS in people with schizophrenia was published in 2003 (Heiskanen, Nieskanen, Lyytikäinen, Saarinen \& Hintikka, 2003). MetS is associated with mental illnesses, and it is indeed a major predictor of mortality and morbidity in mentally ill patients. A large number of studies have been conducted on the prevalence in different contexts and countries, yielding mixed results (24.6-60.8\%) (Table 2 ). Nonetheless, very few studies have examined the relationship between MetS and the quality of life of these people. The first such study done in Europe (Medeiros-Ferreira, Obiols, Navarro-Pastor \& ZuñigaLagares, 2013) shows no relationship between quality of life and MetS in patients with schizophrenia. According to the authors, these findings could be attributed to the instrument used to assess the quality of life of people with schizophrenia (EQ-5D), which focused more on psychic limitations than on physical illness. In a subsequent study, Foldemo et al. (2014) found that quality of life was significantly lower in people with psychosis compared to the general population. They also concluded that this poorer quality of life was not

Tabla 2. MetS prevalence in different schizophrenic populations

\begin{tabular}{lrc}
\hline Author (year), country & N & Prevalence \\
\hline McEvoy et al. (2005) US & 1460 & $40.9 \%$ \\
\hline Sánchez-Araña et al. (2007) Spain & 136 & $36 \%$ \\
\hline Bobes et al. (2007) Spain & 1452 & $24.6 \%$ \\
\hline Sugawara et al. (2010) Japan & 1186 & $27.5 \%$ \\
\hline Mitchell et al. (2011) meta-analysis & 25692 & $32.5 \%$ \\
\hline Medeiros-Ferreira et al. (2013) Spain & 81 & $36.8 \%$ \\
\hline Varela et al. (2013) Spain & 53 & $33.3 \%$ \\
\hline Bajaj et al. (2013) India & 50 & $28 \%$ \\
\hline Gutiérrez-Rojas et al. (2014) Spain & 391 & $59.9 \%$ \\
\hline Morgan et al. (2014) UK & 1642 & $60.8 \%$ \\
\hline
\end{tabular}




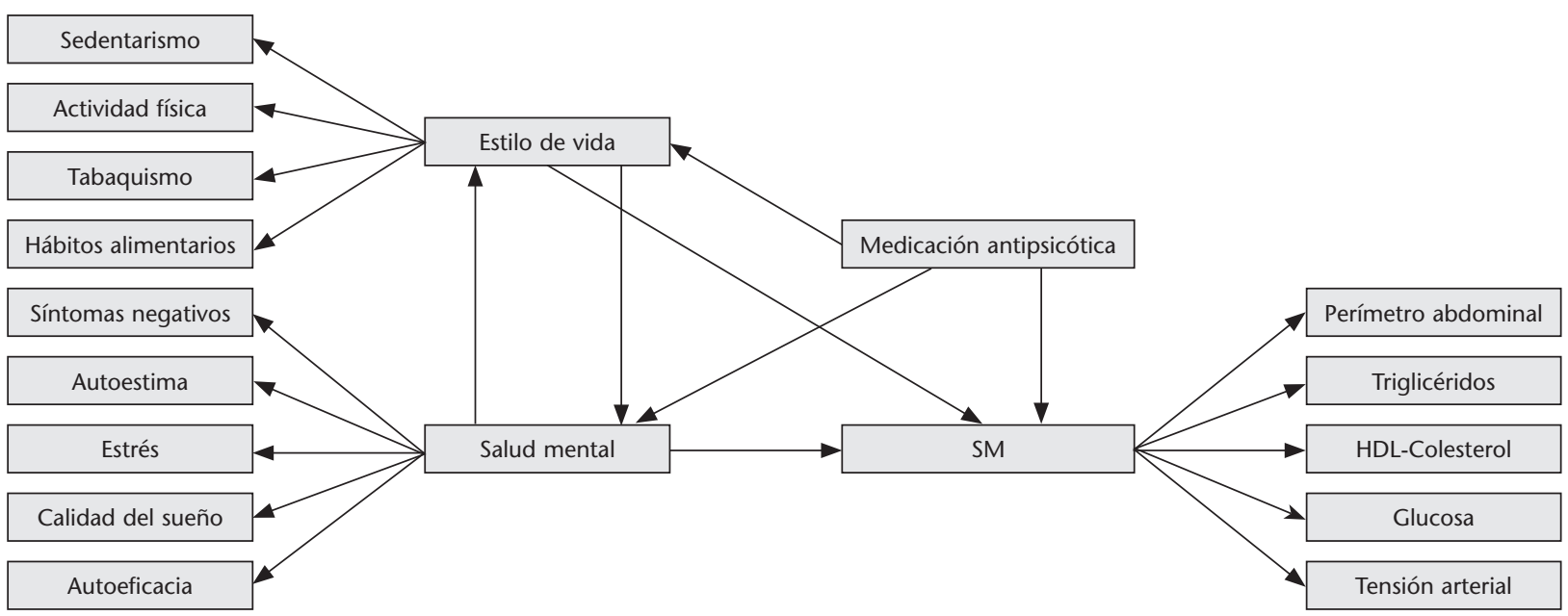

Figure 1. Relation between MetS, lifestyle, mental health variables and antipsychotic drugs in people with schizophrenia (Vancampfort et al., 2010).

related to the presence or absence of MetS, but only in the presence of hypertension.

The "Consensus on physical health of patients with schizophrenia from the Spanish Societies of Psychiatry and Biological Psychiatry" (Sáiz, Bobes, Vallejo, Giner \& García-Portilla, 2008) concluded, after reviewing the scientific literature published on the Medline database through 2006, that MetS is two to four times more prevalent in patients with severe mental disorders (SMD). This prevalence is age-related (it increases with age), sex (more frequent in women) (McEvoy et al., 2005) and ethnicity (prevailing in Hispanics). Figure 1 displays a relational model for MetS, behaviours associated with lifestyle and the mental state of schizophrenic people.

Several articles on the importance and incidence of MetS in people with severe mental illness, especially with schizophrenia, have been published over the past 10 years. A great number of articles have highlighted the importance of taking into account the physical health of people with serious mental illnesses (e.g. Millar, 2010; Morgan et al, 2014; Sánchez-Araña, Touriño, Hernández y León, 2006; Varela et al, 2013) and the influence of these physical problems on their quality of life (e.g. Faugere et al, 2015; Kolotkin, Crosby, Corey-Lisle, Li \& Swanson, 2006; SánchezAraña, Ruiz-Doblado, Hernández-Fleta, TouriñoGonzález \& León-Perez, 2010). However, publications addressing MetS treatment or its risk factors to improve quality of life are scant.

Thus, the aim of this study is to provide an accurate picture of the current state of research in this area and identify potential new areas of study.

\section{Method}

\section{Article search}

PsycINFO and Web of Science databases were used to search for articles for inclusion in the present review. In order to meet the criteria for inclusion the articles had to: (a) be original works whose aim was to study MetS and / or quality of life in people with schizophrenia and (b) provide some information that was not exclusively drug-related. Hence, the keywords used to conduct the search were "MetS", "quality of life", "schizophrenia" and "intervention". Upon a preliminary search with the keywords listed above of articles published through December 2015, 93 articles were found, 23 of which were dismissed as they focused exclusively on the effects of antipsychotic medications associated with MetS or MetS associated with other serious mental disorders and / or other physical disorders. The meta-analysis and revisions with these keywords were also selected. Thus, 70 articles were included in this study. In order to ensure consistency, findings were analysed by other two researchers. There was total agreement on the selected articles.

\section{Article assessment}

For each selected article, an analysis was performed as to the evaluation of MetS in people with schizophrenia, whether or not studies on quality of life were conducted, if there were any recommendations for intervention, and finally, if any action was carried out and an assessment of the results obtained.

Only the information provided in the articles was analysed. No contact was made with any author for further information. A summary of this information can be seen in the following section and in Table 3.

\section{Results}

A large number of journals have published articles analysing MetS in relation to schizophrenia, but fewer have done so in relation to quality of life and far fewer still on how to design and evaluate an intervention.

Only one of the articles included in this review was published in a leading journal like The British Journal of Psychiatry, International Review of Psychiatry or Quality of Life Research. 
Tabla 3. Topics of the articles reviewed

\begin{tabular}{|c|c|c|}
\hline Author, year & Topic & Theme \\
\hline McEvoy et al.,2005 & Prevalence of MetS in USA & $\mathrm{P}$ \\
\hline Meyer et al.,2005 & Group comparison with and without MetS & \\
\hline Cavieres et al.,2005 & Cognitive functioning and quality of life & QL \\
\hline Hoffman et al.,2005 & Intervention in the well-being of people with schizophrenia & QL \\
\hline de Hert et al.,2006 & Impact of weight in the self-esteem of patients with schizophrenia & \\
\hline Kolotkin et al.,2006 & Impact of weight in the quality of life of psychiatric patients & $\mathrm{P}$ \\
\hline Sánchez-Araña et al.,2006 & Revision. Prevalence of MetS in schizophrenia & $\mathrm{P}$ \\
\hline Farriols et al.,2006 & Effectiveness of a psycho-social intervention program & $\mathrm{I}$ \\
\hline Yoon et al.,2007 & Relationship obesity-quality of life & QL \\
\hline Saha et al.,2007 & Revision. Mortality in schizophrenia & $\mathrm{P}$ \\
\hline Nuñez et al.,2007 & Questionnaire to measure quality of life in schizophrenia & QL \\
\hline Bobes et al.,2007 & Quality of life in schizophrenia & QL \\
\hline Narvaez et al.,2007 & Objective and subjective quality of life & QL \\
\hline Lafuente et al.,2007 & Quality of life after deinstitutionalisation & QL \\
\hline Jones et al.,2008 & Effects of antipsychotics in MetS & \\
\hline Loh et al.,2008 & Relation between SMD and weight perception & $\mathrm{P}$ \\
\hline Millar,2008 & Guidelines on the management of physical health & G \\
\hline Maj,2009 & Ethical and public health priority in the assistance to physical health of mentally ill patients & \\
\hline Faulkner et al.,2009 & Revision. Interventions to reduce weight in schizophrenia & $\mathrm{I}$ \\
\hline Maj,2009 & Need to protect and foster physical health of SMD & \\
\hline Fagiolini et al.,2009 & Effects of psycho-educative treatment in MetS & $\mathrm{I}$ \\
\hline McIntirre,2009 & Evaluating attitudes and knowledge in SMD & \\
\hline von Hausswolff-Juhlin et al.,2009 & Evaluating the prevalence of physical problems & $\mathrm{P}$ \\
\hline Morris et al.,2009 & Tobacco treatment to prevent morbidity & \\
\hline Saravane et al.,2009 & Recommendations on physical follow-up in SMD & G \\
\hline Vergara-Rodríguez et al.,2009 & Factors that influence in MetS in HIV & \\
\hline Wysokinski et al.,2009 & Adherence problems in patients and the MetS & \\
\hline Jarne et al.,2009 & Transcultural analysis of quality of life in schizophrenia & QL \\
\hline de Hert et al.,2009 & Revision of MetS and recommendations & G \\
\hline Sugawara et al.,2010 & Prevalence of MetS in Japan & $\mathrm{P}$ \\
\hline Shuel et al.,2010 & Identifying physical problems in SMD & \\
\hline Vancampfort et al.,2010 & Revision on physical activity and risk factors & \\
\hline Millar,2010 & Health screening program in Scotland & \\
\hline Heald,2010 & Evaluation of risk factors and recommendations & G \\
\hline Saiz-Ruiz et al.,2010 & Evaluating the impact of implementing a recommendation guide of physical health follow-up & G \\
\hline Sánchez-Araña et al.,2010 & Comparison of quality of life in groups with and without MetS & QL \\
\hline Vancampfort et al.,2011 & Functional differences in obese-not obese patients & \\
\hline Vancampfort et al.,2011 & Influence of physical activity in quality of life & QL \\
\hline Pompilli et al.,2011 & Effects of antipsychotics in physical health & \\
\hline Martín-Sierra et al.,2011 & Relation between physical activity and quality of life & QL \\
\hline Riordan et al.,2011 & Identifying risk factors in SMD and antipsychotic treatment & \\
\hline Rodríguez-Vida et al.,2011 & Quality of life in schizophrenia & \\
\hline Chacon et al.,2011 & Effectiveness in the intervention on lifestyle & \\
\hline Chandra et al.,2012 & Revision. MetS in women and children & \\
\hline Aguilar et al.,2012 & Etiology of MetS & \\
\hline Bobes-García et al.,2012 & Assessment on the recommendations on physical health & G \\
\hline Knöchel et al.,2012 & Benefits of exercise in quality of life & \\
\hline Medeiros-Ferreira et al.,2013 & Relationship between MetS, quality of life and overall functioning & QL \\
\hline Foguet et al.,2013 & Cardiovascular risk factors and quality of life & QL \\
\hline Sugawara et al.,2013 & Relationship between quality of life and BMI in Japan & QL \\
\hline Yarborough et al.,2013 & Program of intervention in lifestyle & $\mathrm{I}$ \\
\hline Beebe et al.,2013 & Evaluation of the physical activity & \\
\hline Deuschle et al.,2013 & Cardiovascular risk evaluation in Germany & \\
\hline$\underline{\text { Boyer et al.,2013 }}$ & Association between MetS and inflammation & \\
\hline Bajaj et al.,2013 & Association between MetS and schizophrenia & \\
\hline Lopera et al.,2013 & Effectiveness in nursing interventions in MetS & $\mathrm{I}$ \\
\hline Viñas et al.,2013 & $\begin{array}{l}\text { Effectiveness in a collaboration program between primary care and mental health to improve the } \\
\text { cardiovascular risk }\end{array}$ & I \\
\hline Mitchell et al.,2013 & Meta-analysis in the prevalence of MetS & $\mathrm{P}$ \\
\hline Varela et al.,2013 & Prevalence of MetS & $\mathrm{P}$ \\
\hline Foldemo et al.,2014 & Quality of life and MetS & QL \\
\hline Crawford et al.,2014 & Revision on the evaluation of physical health in Great Britain & \\
\hline Bly et al.,2014 & Lifestyle and MetS & \\
\hline Gutiérrez-Rojas et al.,2014 & Prevalence of MetS & $\mathrm{P}$ \\
\hline Morgan et al.,2014 & Prevalence of psicosis and physical comorbidities in Australia & \\
\hline
\end{tabular}


Tabla 3. Topics of the articles reviewed (cont.)

\begin{tabular}{|c|c|c|}
\hline Author, year & Topic & Theme \\
\hline Rönngren et al., 2014 & Assess intervention on lifestyle & I \\
\hline Strassing et al., 2014 & Intervention model in DMS & $\mathrm{I}$ \\
\hline Suttajit et al., 2015 & Biological and psychosocial factors as predictors of quality of life & QL \\
\hline Faugere et al., 2015 & Impact of the symptoms of schizophrenia in quality of life & QL \\
\hline Bartoli et al., 2015 & Meta-analysis on the prevalence of MetS & $\mathrm{P}$ \\
\hline van Hasselt et al., 2015 & Recommendation guide on the management of physical health & G \\
\hline
\end{tabular}

$\mathrm{P}=$ prevalence; $\mathrm{QL}=$ quality life; I=intervention; $\mathrm{G}=$ guideline recommendations

The selected papers were published between 2005 and 2015 (it was fixed a period of the last 10 years), but most of them were published in 2009 and 2013. There is no doubt that there are different thematic areas in the study at hand, but the ones that bring together a large number of literature are (Table 3):

- Studies on the prevalence of MetS in different contexts $(\mathrm{P})$

- Recommendations as to guidelines and other activities for the management of the physical health of the mentally ill $(\mathrm{G})$

- Quality of life in relation to different areas (body weight, physical activity, lifestyle and others) (QL) Of all the articles analysed, only 8 dealt with intervention. Therefore, it is important to note the conclusion of Medeiros-Ferreria et al. (2013) that "the association between MetS and physical activity reinforces the importance of stressing healthy life habits and the need for interventions to promote customary physical activity" regarding this reality.

Some of the findings in different studies on quality of life in relation to MetS demonstrate that obesity is one of the most influential factors in the poor subjective quality of life of these patients (Heald, 2010; Kolotkin et al., 2006; McIntyre, 2009; Sugawara et al, 2013). Heald (2010) pointed out that physical health problems that affect schizophrenic people could lead to a poor quality of life and self-esteem as well as reduce their life expectancy. However, Foguet et al. (2013) did not find any relationship between cardiovascular risk and quality of life. On the other hand, there is agreement about the unhealthy aspects of the quality of the dietthese patients tend to consume, which is high in saturated fats and sugars and poor in fruits and fibre (Dipasquale, Pariante, Dazzan, Aguglia, McGuire \& Modelli, 2013). Meanwhile, Foldemo et al. (2014) write that patients suffering from psychosis had significantly lower health-related QL compared to a population-based reference sample. According to these authors, the only risk factor included in the metabolic syndrome that was associated with QL was elevated blood pressure.

Some of the most frequent indications in different articles are summarized in the Ten Commandments of Consensus written by Saiz et al. (2008), a text that confirms that the great impact on physical health of patients with schizophrenia is due to genetic factors, factors inherent in the disease itself, the lifestyle of these patients and treatment with antipsychotic drugs. The physical health of patients with schizophrenia can and should be improved, and hence it is of the utmost importance to develop and implement specific psychoeducational programs, paying special attention to the most commonly affected aspects of physical health in these patients.

Several studies (Enguita-Flórez, 2014; Saravane et al, 2009; Viñas, Fernández \& Martín, 2013; Yarborough, Leo, Stumbo, Perrin \& Green, 2013) tackled the aspects to be taken into account when designing an intervention in this area. Chacon et al. (2011) illustrated these considerations, as shown in Figure 2.

The most widespread consensus on the approach to intervention in people with MetS and schizophrenia can be summarized as follows:

- Physical activity has a mild to moderate positive effect on many metabolic and cardiovascular risk factors constituting MetS or related with it (de Hert et al., 2009).

- There is evidence that formal dietary counselling and group exercise can help people with schizophrenia to achieve better physical health (Cimo, Stergiopoulos, Cheng, Bonato \& Dewa, 2012; Daumit, Dickerson, Wang, Dalcin, Jerome \& Anderson, 2013).

- Among the benefits of regular physical activity are a reduced risk of arteriosclerosis, obesity and hypertension, as well as improvements in lipid profiles and glucose tolerance (von Hausswolff et al., 2008). Additionally this activity brings with it social interaction, increased self-esteem and improvements in sleep patterns.

- It has been observed that smoking cessation can reduce cardiovascular risk in people with schizophrenia by up to $75 \%$ (Bobes, Arango, GarcíaGarcía \& Rejas, 2010).

\section{Discussion and conclusion}

This paper presents a synopsis of current knowledge on MetS in schizophrenia and on this syndrome's impact on the quality of life of the people affected. The data provided can lay the foundation for treatment in light of the numerous consensus guidelines on this subject. Therefore, based on 70 publications we can conclude that:

- Some factors related to mental illness, such as the side effects of medications, unhealthy life styles, and possible genetic vulnerability, increase the likelihood of health problems and comorbid medical conditions in people with schizophrenia. 


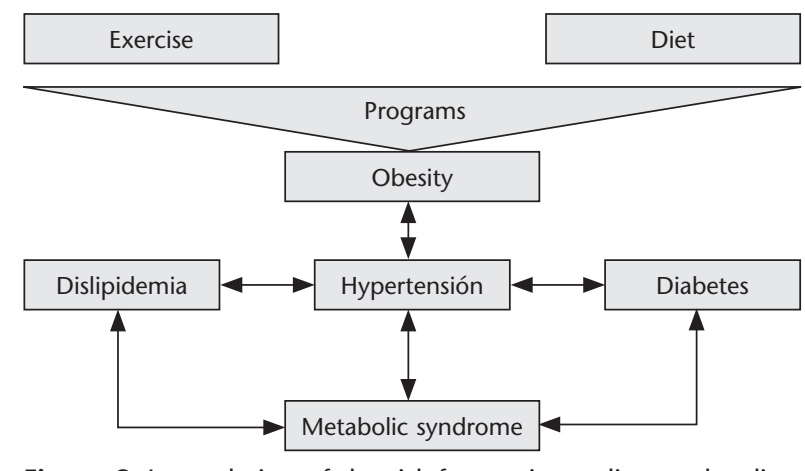

Figure 2. Interrelation of the risk factors in cardiovascular disease and the actions carried out in the style of life intervention programs (Chacon et al., 2011)

- The physical health of people with schizophrenia is worse than that of the general population due to inherent aspects of the illness and to dual negligence on the part of the health system. According to our review, awareness of this problem should be raised among mental health professionals, primary care professionals, people with schizophrenia, their families and the general population.

- As shown in a number of studies (Table 2), the prevalence of MetS is higher than in the general population, resulting in a poorer quality of life and a decrease in life expectancy.

- Despite the proven knowledge of MetS in people with schizophrenia in different studies and different countries, the frequency and quality of the monitoring of these patients is still poor.

- A number of professionals have suggested that the physical health of people with schizophrenia should be monitored by evaluating and carrying out ongoing follow-up, in addition to establishing protocols for collaboration among mental health professionals and primary care professionals for a comprehensive approach to SMD. Moreover, psychoeducational programs should be designed to take into account the particular characteristics of people with schizophrenia to improve their physical health and quality of life.

Having identified the difficulties involved in caring for these patients, it high time that we move on from theory to action. It is a top priority to carry out activities that have been proven effective in addressing these diseases in the primary, secondary and tertiary prevention phases. It may seem obvious to conclude that a healthy life coupled with a healthy diet and regular physical activity is an effective way to achieve good physical health, even for people with schizophrenia, but the reason why these patients do not take steps to improve their physical health is still unanswered.

Meanwhile, only a few studies have looked at the application of ehealth devices to schizophrenic patients (Shin et al., 2016). However, there is a growing interest in mobile health intervention in patients with psychosis (Bonet et al., 2017). The use of ehealth devices showed a promising degree of feasibility for this population.
Any intervention to improve the physical health of these patients should take into account the interrelationship of cardiovascular risk factors and include the following:

- A psychoeducational approach to healthy eating and exercise habits. Changes should be gradual in order to be incorporated progressively into their lifestyle.

- Specially designed intervention for people with schizophrenia to achieve a reduction or cessation in tobacco consumption.

- Lifestyle interventions require adaptation for this group because psychiatric symptoms and cognitive impairment are highly prevalent. (Daumit et al., 2013).

The most important limitation of this study is that there are very few articles that combine the four keywords. While we found many articles with two or three of our topics, few combined all of them. More research in this specific area will be necessary for a better comprehension of MetS that could provide better interventions for this population.

For the aforementioned reasons, and in conclusion we believe that implementing intervention programs with proven efficacy in reducing cardiovascular risk would be a good therapeutic action on behalf of the people with schizophrenia we serve. More research in these directions will help the intervention in people with this diagnosis.

\section{Conflict of interest statement}

The authors declare that the research was conducted in the absence of any commercial or financial relationship that could be construed as a potential conflict of interest.

\section{Acknowledgementes}

This study was supported by a grant from the Fundació Docència i Recerca Mútua Terrassa.

\section{References}

Adult Treatment Panel III. (2001). Third Report of the National Cholesterol Education Program (NCEP) expert panel on detention, evaluation and treatment of high blood cholesterol in adults. Journal of the American Medical Association,285, 2486-2497.

Aguilar, E., Coronas, R. \& Caixàs, A.(2012).Síndrome metabólico en pacientes esquizofrénicos con tratamiento antipsicótico. Medicina Clinica, 139(12),542-546. doi:10.1016/j.medclin.2012.05.028

Albert, U., Aguglia, A., Chiarle, A., Bogetto, F. \& Maina, G.(2013). Metabolic syndrome and obsessive-compulsive disorder: a naturalistic Italian study. General Hospital Psychiatry,35, 154-159.doi:10.1016/j.genhosppsych.2012.10.004

Bajaj, S., Varma, A., Srivastava, A. \& Kumar, A. (2013). Association of metabolic syndrome with schizophre- 
nia. Indian Journal of Endocrinology and Metabolism,17(5), 890-895. doi:10.4103/2230-8210.117238 Bartoli, F., Crocamo, C., Caslini, M., Clerici, M. \& Carrà, G.(2015). Journal of Psychiatric Research,66-67,127-134. doi:10.1016/j.jpsychires.2015.04.028

Beebe, L. \& Harris, R.(2013). Description of physical activity in outpatients with shizophrenia spectrum disorders.International Journal of Mental Health Nursing,22,430-436.doi:10.1111/inm.12008

Bernardo, M., Cañas, F., Banegas, J., Casademont, J., Riesgo, Y. \& Varela, C.(2009). The RICAVA Study Group. Prevalence and awareness of cardiovascular risk factors in patients with schizophrenia: a cross sectional study in a low cardiovascular disease risk geographical area. European Psychiatry,24,431-441

Bly, M. et al. (2014). Metabolic syndrome in bipolar disorder and schizophrenia: dietary and lifestyle factors compared to the general population. Bipolar disorders, 16(3)277-288. doi:10.111/bdi.12160

Bobes, J., Arango, C., Aranda, P., Carmena, R., GarciaGarcia, M. \& Rejas, J. (2007). Casdiovascular and metabolic risk in outpatients with schizophrenia treated with antipsychotics: results of the CLAMORS Study. Schizophrenia Research,90, 162-173.

Bobes,J., Arango,C., García-García,M. \& Rejas,J.(2010). Healthy lifestyle habits and 10-years cardiovascular risk in schizophrenia spectrum disorders: an analysis of the impact of smoking tobacco in the CLAMORS schizophrenia cohort. Schizophrenia Research,119, 101-109.

Bobes-García, J., Saiz-Ruiz, J., Bernardo-Arroyo, M., Caballero-Martínez, F., Gilaberte Asín, I. \& CiudadHerrera, A. (2012). Consenso Delphi sobre la salud física del paciente con esquizofrenia: valoración por un panel de expertos de las recomendaciones de las sociedades españolas de psiquiatría y psiquiatría biológica. Actas Españolas Psiquiatría, 40(3),114-128.

Bonet, L., Izquierdo, C., Escartí, M.J., Sancho, J.V., Arce, D., Blanquer, I. \& Sanjuan, J. (2017). Utilización de tecnologías móviles en pacientes con psicosis: una revisión sistmática. Revista de Psiquiatría y Salud Mental. 10 (3), 168.178. doi:10.1016/j.rpsm.2017.01.003

Boyer, L., Richieri, R., Dassa, D., Boucekine, M., Fernandez, J., Vaillant, F., Padovani, R., Auquier, P. \& Lancon, C. (2013). Association of metabolic syndrome and inflammation with neurocognition in patients with schizophrenia. Psychiatry Research,210,381-386. doi:10.1016/j.psychres.2013.06.020

Cavieres, A. \& Valdebenito, M. (2005). Funcionamiento cognitivo y calidad de vida en la esquizofrenia. Revista Chilena Neuro-Psiquiatría,43(2),97-108.

Cimo, A., Stergiopoulos, E., Cheng, C., Bonato, S. \& Dewa, C. (2012). Effective lifestyle interventions to improve type II diabetes self-management for those with schizophrenia or schizoaffective disorder: a systematic review. BMC Psychiatry,12-24.

Chacon, F., Mora, F., Gervás-Ríos, A. \& Gilaberte, I. (2011). Efficacy of lifestyle interventions in physical health management of patients with severe mental illness. Annals of General Psychiatry,10-22.
Chandra, P., Sagar, J. \& Rudhran, V.(2012). Schizophrenia in women and children: a selective review of literature from developing countries. International Review of Psychiatry,24(5),467-482. doi:10.3109/095 40261.2012.707118

Crawford, M., Jayakumar, S., Lemmey, S., Zalewska, K., Patel, M., Cooper, S. \& Shiers, D. (2014). Assessment and treatment of physical health problems among people with schizophrenia: national cross-sectional study. The British Journal of Psychiatry,205(6),473-477. doi:10.1192/bjp.bp.113.142521

Daumit, G., Dickerson, F., Wang, N., Dalcin, A., Jerome,G. \& Anderson,C.(2013). A behavioral weight-loss intervention in persons with serious mental illness. New England Journal of Medicine, 368, 1594-1602.

de Hert, M., Peuskens, B., van Winkel, R., Kalnicka, D., Hanssens, L., van Eyck, D., Wyckaert,S. \& Peuskens, J. (2006). Body weight and self-esteem in patients with schizophrenia evaluated with B-WISE. Schizophrenia Research, 88, 222-226. doi:10.1016/j.schres.2006.07.025 de Hert,M., Schreurs,V., Vancampfort,D. \& van Winkel, R. (2009). Síndrome metabólico en personas con esquizofrenia: una revisión. World Psychiatry, 7,15-22.

Deuschle, M., Paul, F., Brosz, M., Bergemann, N., Franz, M., Kammerer-Ciernioch, J., ... \& Kahl, K. G. (2013). Assessment of cardiovascular disease risk in patients with schizophrenia spectrum disorders in German psychiatric hospitals: results of the pharmacoepidemiologic CATS study. Social psychiatry and psychiatric epidemiology, 48(8), 1283-1288.doi:10.1007/s00127013-0676-0

Dipasquale, S., Pariante, C., Dazzan, P., Aguglia, E., McGuire, P. \& Modelli, V.(2013). The dietary pattern of patients with schizophrenia:A systematic review. Journal of Psychiatric Research, 47,197-207.

Enguita-Flórez, M.P. (2014).Efectos de un programa de actividad física en trastorno mental grave. Rehabilitación psicosocial, 11(1), 17-27.

Fagiolini, A. \& Goracci, M. (2009).The effects of undertreated chronic medical illnesses in patients with severe mental disorders. Journal Clinical Psychiatry, 70(3),22-29. doi:10.4088/JCP.7075sulc.04

Farriols, N., Palma, C., Ramos, M., Fernández, M., Chamorro, A., Polo, Y. \& Botella, Ll. (2006). Efectividad de un programa de intervención psicosocial en pacientes psicóticos crónicos. Clínica y Salud,17(2), 171-185.

Faugere, M., Micoulaud-Franchi, J.A., Alessandrini, M., Richieri, R., Faget-Agius, C., Auquier, P., Lançon, C. \& Boyer, L. (2015). Quality of life is associated with chronic inflammation in schizophrenia: a crosssectional study. Scientific Reports,1-7.doi:10.1038/ srep10793

Faulkner, G., Cohn, T. \& Remington, G. (2009). Interventions to reduce weight gain in schizophrenia. Schizophrenia Bulletin,33(3),654-656.doi:10.1093/ schbul/sbm022

Foguet, Q., Roura, P., Bullón, A., Mauri, C., Gordo, N. \& Cecília, R. (2013). Factores de riesgo cardiovascular, 
riesgo cardiovascular y calidad de vida en pacientes con trastorno mental severo. Atención Primaria, 45(3), 141-148. doi:10.1016/j.aprim.2012.10.010

Foldemo, A., Wärdig, R., Bachrach-Lindström, M., Edman, G., Holmberg, T., Lindström, T., Valter, L. \& Ösby, U. (2014). Health-related quality of life and metabolic risk in patients with psychosis. Schizophrenia Research, 152, 295-299. doi:10.1016/j. schres.2013.11.029

Gutierrez-Rojas, L., Azanza, J., Bernardo, M., Rojo, L., Mesa, F. \& Martínez-Ortega, J.M. (2014). Prevalencia del síndrome metabólico en pacientes españoles con esquizofrenia y sobrepeso. El estudio CRESSOB. Actas Españolas Psiquiatría,42(1),9-17.

Heald, A.(2010).Physical health in schizophrenia: a challenge for antipsychotic therapy. European Psychiatry,25,6-11.

Heiskanen, T., Niskanen, L., Lyytikainen, R., Saarinen,P. $\&$ Hintikka,J.(2003). Metabolic syndrome in patients with schizophrenia. Journal Clinical Psychiatry,64,575-579.

Hoffmann, V., Ahl, J., Meyers, A., Schuh, L, Shults, K, Collins,D. \& Jensen,L.(2005). Wellness intervention for patients with serious and persistent mental illness. Journal Clinical Psychiatry,66(12),1576-1579.

Jarne, A., Villaseñor, T., Guàrdia, J., Arroyo, M. \& Peiró, M. (2009).Transcultural study on quality of life in patients diagnosed of schizophrenia from Mexico and Spain. Escritos de psicología,2(3),1-7.

Jones, M. \& Jones, A. (2008).The effect of antipsychotic medication on metabolic syndrome. Nursing Standard,22(48), 43-48.

Kato, M., Currier,M., Villaverde,O. \& González-Blanco, M. (2005). The relation between body fat distribution and cardiovascular risk factors in patients with schizophrenia: a cross-sectional pilot study. Primary Care Companion Journal Clinical Psychiatry,7, 115-120.

Knöchel, C., Oertel-Knöchel, V., O'Dwyer, L., Prvulovic, D., Alves, T., Kollman, B. \& Hampel, H. (2012). Cognitive and behavioural effects of physical exercise in psychiatric patients. Progress Neurobiology,96(1),46-68. doi:10.1016/j.neurobio.2011.11.007

Kolotkin, R., Crosby, R., Corey-Lisle, P., Li, H. \& Swanson, J. (2006). Performance of a weight-related measure of quality of life in a psychiatric sample. Quality of Life Research,15,587-596.doi:10.1007/ s11136-005-4627-4

Lafuente, S., Francisco, J., Criado, I. \& Covarrubias, C. (2007). Desinstitucionalización y calidad de vida en pacientes esquizofrénicos. El caso de Segovia. Revista Asociación Española Neuropsiquiatría,27(100),319-331.

Loh, C., Meyer, J.M. \& Leckband, SG. (2008). Accuracy of body image perception and preferred weight loss strategies in shizophrenia: a controlled pilot study. Acta Psychiatrica Scandinavica,117,127-132. doi:10.1111/j.1600-0447.2007.01123.x

Lopera, M.J., Pérez, L. \& Utrera, E. (2013). Eficacia de la intervención enfermera en la prevención del síndrome metabólico en pacientes con esquizofrenia. Revista Paraninfo Digital,19.
Maj, M. (2009a). La asistencia sanitaria física en personas con enfermedades mentales graves: una prioridad de salud pública y ética. World Psychiatry,7,1-2.

Maj, M. (2009b). Necesidad de proteger y fomentar la salud física en personas con enfermedad mental grave. Revista Psiquiatría Salud Mental,2(1),1-4.

Martín-Sierra, A., Vancampfort, D., Probst, M., Bobes, J., Maurissen, K., Sweers, K., de Schepper, E. \& de Hert, M. (2011). Walking capacity is associated with health related quality of life and physical activity level in patients with schizophrenia: a preliminary report. Actas Españolas Psiquiatría,39(4),211-216.

McEvoy, J., Meyer,J., Goff,D., Nasrallah,H., Davis,S., Sullivan,L., Meltzer, H.Y., Hsiao, J., Scott, T. \& Lieberman, J. (2005). Prevalence of the metabolic syndrome in patients with schizophrenia: baseline results from the Clinical Antipsychotic Trials of Intervention Effectiveness (CATIE) schizophrenia trial and comparison with national estimates from NHANES III. Schizophrenia Research,80(1),19-32.

McIntyrre, R. (2009).Understanding needs, interactions, treatment, and expectations among individuals affected by bipolar disorder or schizophrenia: the UNITE global survey. Journal Clinical Psychiatry,70(3),5-11. doi:10.4088/JCP.7075sulc.02

Medeiros-Ferreira, L., Obiols, J., Navarro-Pastor, J. \& Zúñiga-Lagares, A. (2013). Metabolic syndrome and health-related quality of life in patients with schizophrenia. Actas Españolas Psiquiatría,41(1),17-26.

Meyer, J., Nasrallah, H., McEvoy, J., Goff, D., Davis, S., Chakos, M., Patel, J., Keefe, R., Stroup, T. \& Lieberman, J. (2005). The Clinical Antipsychotic Trials of Intervention Effectiveness (CATIE) Schizophrenia Trial: clinical comparison of subgroups with and without the metabolic syndrome. Schizophrenia Research,80,9-18.doi:10.1016/j.shres.2005.07.015

Millar, H. (2008). Management of physical health in shizophrenia: a stepping stone to treatment success. European Neuropsychopharmacology,18, S121-S128. doi:10.1016/j.euroneuro.2008.02.002

Millar, H. (2010). Development of a health screening clinic. European Psychiatry,25, 29-33.

Mitchell, A., Vancampfort, D., Sweers,K., van Winkel,R., Yu,W. \& de Hert,M.(2011). Prevalence of metabolic syndrome and metabolic abnormalities in schizophrenia and related disorders - a systematic review and meta-analysis. Schizophrenia Bulletin,39(2),306-318.doi:10.1093/schbul/sbr148

Morgan, V., McGrath, J., Jablensky, A., Badcock, J., Waterreus, A., Rush, R., Carr, V., Castle, D., Cohen, M., Galletly, C., Harvey, C., Hocking, B., McGorry, P., Neil, A., Saw, S., Shah, S., Stain, J. \& Mackinnon, A. (2014). Psychosis prevalence and physical, metabolic and cognitive co-morbidity: data from the second Australian national survey of psychosis. Psychological Medicine, 44, 2163-2176. doi:10.1017/ S0033291713002973

Morris, C., Waxmonsky, J., May, M. \& Giese, A. (2009). What do persons with mental illnesses need to quit smokint? Mental health consumer and provider 
perspectives. Psychiatric Rehabilitation Journal,32(4),276-284.doi:10.2975/32.4.2009.276.284

Narvaez, J., Twamley, E., McKibbin, C., Heaton, R. \& Patterson,T.(2008). Subjective and objective quality of life in schizophrenia. Schizophrenia Research, 98, 201-208. doi:10.1016/j.schres.2007.09.001

Nuñez, D., Acuña, F., Rojas, G. \& Vogel, E. (2007). Construcción y validación inicial de un cuestionario para medir calidad de vida en pacientes esquizofrénicos. Revista Chilena Neuro-Psiquiatría,45(2),148-160. doi:10.4067/S0717.92272007000200008

Pompili, M., Serafini, G., Innamorati, M., Ambrosi, E., Telesforo, L., Venturini, P., Giordano, G., Battuello, M., Lester, D. \& Girardi, P. (2011). Unmet treatment needs in schizophrenia patients: is asenapine a potential therapeutic option? Expert Review Neurotherapeutics, 11(7),989-1006.

Riordan, H., Antonini, P. \& Murphy, M. (2011). Atypical antipsychotics and metabolic syndrome in patients with schizophrenia: risk factors, monitoring, and healthcare implications. American Health and Drug Benefits, 4(5),292-302.

Rodríguez-Vidal, M., Castro-Salas, M., Sanhueza-Escobar, V., del Valle-Utreras, A. \&Martínez-Arriagada, J. (2011). Calidad de vida en pacientes esquizofrénicos. Aquichan,11(1),66-76.

Rönngren, Y., Björk, A., Haage, D. \& Kristiansen, L. (2014). LIFEHOPE.EU: lifestyle and healthy outcome in physical education. Journal of Psychiatric and Mental Health Nursing,21,924-930.doi:10.1111/ jpm. 12175

Saha, S., Chant, D. \& McGrath, J. (2007). A systematic review of mortality in schizophrenia. Archives General Psychiatry, 64(10),1123-1131.

Saiz, J., Bobes, J., Vallejo, J., Giner, J. \& García-Portilla, M.P. (2008).Consenso sobre la salud física del paciente con esquizofrenia de las Sociedades Españolas de Psiquiatría y de Psiquiatría Biológica. Actas Españolas Psiquiatría,36(5),251-264.

Saiz-Ruiz, J., Saiz-González, M.D., Alegría, A., Mena, E., Luque, J. \& Bobes, J. (2010). Impacto del consenso español sobre la salud física del paciente con esquizofrenia. Revista Psiquiatría y Salud Mental, 3(4),119-127.doi:10.1016/j.rpsm.2010.11.001

Sánchez-Araña, T., Ruiz-Doblado, S., Hernández-Fleta, J.L., Touriño-González, R. \& León-Pérez, P. (2010). Quality of life in a sample of schizophrenia patients with and without metabolic syndrome. Journal of Psychiatric Intensive Care,6(2),101-108.doi:10.1017/ S174264641000017

Sánchez-Araña, T., Touriño, R., Hernández, J.L. \& León, P. (2006). Alta prevalencia de síndrome metabólico en pacientes esquizofrénicos: una revisión de la literatura. Psiquiatría Biológica,13(4),127-135.

Saravane, D., Feve, B., Frances, Y., Corruble, E., Lancon, C., Chanson, P., Maison, P., Terra, J. \& Azorin, J.M. (2009). Élaboration de recommandations pour le suivi somatique des patients atteints de pathologie mentale sévère. L'Encéphale,35,330-339.doi:10.1016/j. encep.2008.10.014
Shin, S., Yeam, Ch., Shin, Ch., Jeong, J.H., Shin, Y. y Lee, Y. (2016). Activity monitoring using a mHealht device and correlations with psychopathology in patients with chronic schizophrenia. Psychiatry Research, 246, 712-718. doi:10.1016/psychres.2016.10.059

Shuel, F., White, J., Jones, M., \& Gray, R. (2010). Using the serious mental illness health improvement profile [HIP] to identify physical problems in a cohort of community patients: A pragmatic case series evaluation. International Journal of Nursing Studies,47,136-145.doi:10.1016/j.ijnurstu.2009.06.003

Strassing, M. \& Harvey, P.(2014). Treatment resistance and other complicating factors in the management of schizophrenia. CNS Spectrums, 19,16-24. doi:10.1017/S1092852914000571

Sugawara, N., Yasui-Furukori, N., Sato, Y., Saito, M., Furukori, H., Nakagami, T., Kudo, S. \& Kaneko, S. (2013). Body mass index and quality of life among outpatients with schizophrenia in Japan. BMC Psychiatry, 13(108), 1-6.

Sugawara, N., Yasui-Furukori, N., Sato, Y., Umeda, T., Kishida, K., Yamashita, H., Saito, M., Furukori, H., Nakagami, T., Hatakeyama, M., Nakaji, S. \& Kaneko, S. (2010). Prevalence of metabolic syndrome among patients with schizophrenia in Japan. Schizophrenia Research, 123, 244-250. doi:10.1016/j.schres.2010.08.030

Suttajit, S. \& Pilakanta, S. (2015). Predictors of quality of life among individuals with shizophrenia. Neuropsychiatric Disease and Treatment,11,1371-1379.

Vancampfort, D., Knape, J., Probst, M.,van Winkel, R., Deckx, S., Maurissen, K., Peuskens, J. \& de Hert, M. (2010). Considering a frame of reference for physical activity research related to the cardiometabolic risk profile in schizophrenia. Psychiatry Research,177,271-279. doi:10.1016/j.psychres.2010.03.011

Vancampfort, D., Probst, M., Scheewe, T., Maurissen, K., Sweers, K., Knapen, J. \& de Hert, M. (2011). Lack of physical activity during leisure time contributes to an impaired health related quality of life in patients with schizophrenia. Schizophrenia Research,129,122-127.doi:10-1016/j.schres.2011.03.018

Vancampfort, D., Probst, M., Scheewe, T., Maurissen, K., Sweers, K., Knapen, J. \& de Hert, M. (2011). Relationships between obesity, functional exercise capacity, physical activity participation and physical self-perception in people with schizophrenia. Acta Psychiatrica Scandinavica,123,423-430.doi:10.1111/ j.1600-0447.2010.01666.x

van Hasselt, F., Out, M. \& Loonen, J. (2015). Practical recommendations for improvement of the physical health care of patients with severe mental illness. Acta Psychiatrica Scandinavica,131(5),387-396. doi:10.1111/acps.12372

Varela, M.J., Fernández, M.J., López, M.J., Nieto, M.J., Pereiro, E. \& Gándara, C. (2013). Prevalencia del síndrome metabólico en esquizofrenia y trastorno bipolar. ¿Sería útil un protocolo de control cardiovascular? Cuadernos Atención Primaria,19,215-222.

Vergara-Rodríguez, P., Vibhakar, S. \& Watts, J. (2009). Metabolic syndrome and associated cardiovascular 
risk factors in the treatment of persons with human immunodeficiency virus and severe mental illness. Pharmacology \& Therapeutics, 124, 269-278. doi:10.1016/j.pharmthera.2009.07.004

Viñas, L., Fernández, M.I., Martín, L. \& Grupo Psicosis Litoral. (2013). Efectividad de un proyecto de colaboración entre atención primaria y salud mental para mejorar el registro de factores de riesgo cardiovascular en pacientes con psicosis. Atención Primaria,45(6),307-314.doi:10.1016/j.aprim.2012.12.008 von Hausswolff-Juhlin, Y., Bjartveit, M., Lindström, E. \& Jones, P. (2009). Schizophrenia and physical health problems. Acta Psychiatrica Scandinavica,119(438),15-21. doi:10.1111/j.1600-0447.2008.01309.x

Wysokinski, A., Talarowska, M., Orzechowska, A., Zboralski, K., Galecki, P. \& Florkowski, A. (2009).Current trends in pharmacological treatment of schizophrenia presented on the XIV World Congress of Psychiatry. Archives of Psychiatry and Psychotherapy,3,5-9.

Yarborough, B., Leo, M., Stumbo, S., Perrin, N. \& Green, C. (2013). STRIDE: a randomized trial of a lifestyle intervention to promote weight loss among individuals taking antipsycotis medications. BMC Psychiatry,13, 238. 
